ZOOLOGIA 31 (2): 175-180, April, 2014

http://dx.doi.org/10.1590/S1984-46702014000200009

\title{
Emended diagnosis of Xeronycteris vieirai (Mammalia: Chiroptera), with the first record of polyodontia for the genus
}

\author{
Marcelo R. Nogueira',3, Renato Gregorin² \& Adriano L. Peracchi ${ }^{1}$
}

\begin{abstract}
${ }^{1}$ Laboratório de Mastozoologia, Instituto de Biologia, Universidade Federal Rural do Rio de Janeiro. 23890-000 Seropédica, RJ, Brazil; E-mail: nogueiramr@gmail.com; alperacchi@yahoo.com.br

${ }^{2}$ Departamento de Biologia, Universidade Federal de Lavras.37200-000 Lavras, MG, Brazil. E-mail: rgregorin@dbi.ufla.br

${ }^{3}$ Corresponding author.
\end{abstract}

\begin{abstract}
The Caatinga-endemic nectar-feeding bat, Xeronycteris vieirai Gregorin \& Ditchfield, 2005 was described based on four specimens. Since then, only two additional specimens have been reported in the literature. Examination of a new specimen that closely agrees with the original description but presents two additional upper premolars, led us to review the type series of this taxon. Our analysis provided support to the recognition of the new specimen as a $X$. vieirai with supernumerary teeth and revealed new diagnostic characters that can help in the field identification of this species. Xeronycteris vieirai presents tricolored dorsal fur, entirely naked forearm, connection of the base of the spear of the noseleaf with the upper limit of the horseshoe with a marked ridge, and chin with simple dermal pads and a relatively slight cleft. Additional new characters described here include anterior zygomatic arches reduced and not extending laterally and upward with respect to upper toothrow, basioccipital pits deep and separated by a high and thin bone septum, and mandible with a pronounced ridge at anterior symphysis. We propose an emended diagnosis based on morphological characters and provide a rectification on the original notation related to the holotype.
\end{abstract}

KEY WORDS. Lonchophylla bokermanni; morphology; supernumerary teeth; taxonomy; Vieira's flower bat.

Eighteen species are currently recognized within Lonchophyllinae, three of which belong to the monotypic Lionycteris Thomas, 1913, Platalina Thomas, 1928, and Xeronycteris Gregorin \& Ditchfield, 2005 (GrifFiths \& GaRDNER 2008), and all others to Lonchophylla Thomas, 1903 (WoOdman 2007, DÁvalos \& Corthals 2008, Dias et al. 2013). While most lonchophyllines occur in rainforest habitats, some species have been found only in drier environments (GRIfFITHS \& GARDNER 2008). This is the case of Vieira's-flower bat Xeronycteris vieirai Gregorin \& Ditchfield, 2005, known from only six localities and seven specimens, all collected in the semi-arid Caatinga of northeastern Brazil (GregoriN \& Ditchfield 2005, Astúa \& Guerra 2008, Nogueira et al. 2007).

The type series of $X$. vieirai is composed of four specimens, as follows: an adult female (MZUSP 14170) and a subadult male (MZUSP 14173) obtained in 1973 in the municipality of Cocorobó, state of Bahia; an adult female (MZUSP 14804) collected in 1978 in the municipality of Exu, state of Pernambuco (see below for the status of this specimen); and an adult male (MZUSP 29777), assigned as the holotype, collected in 1993 in the municipality of Soledade, state of Paraíba (Gregorin \& Ditchfield 2005). As revealed by original notations in tags, MZUSP 14170 and 14173 were first referred to as Lonchophylla bokermanni Sazima, Vizotto \& Taddei, 1978. More recently, additional material of $X$. vieirai was reported in the literature, bringing a new record for the state of Pernambuco (Astúa \& Guerra 2008) and the first mention of the species for the states of Sergipe (AstúA \& Guerra 2008) and Minas Gerais (Nogueira et al. 2007).

Upon examining the specimen from the region of Jaíba, state of Minas Gerais (Nogueira et al. 2007), we noticed that it closely agrees with the original description of $X$. vieirai, differing from it by the presence of additional upper premolar. Aiming to consistently access the taxonomic identification of this specimen, we directly compare it with the type series of $X$. vieirai. Our analysis confirmed the first case of polyodontia for this taxon, and led us to propose an emended diagnosis that will further help to recognize this endemic bat even in the field. Because the original description lacks a detail account of external characters, our emended diagnosis is preceded by a revised description of those morphological traits, and by additional comments on craniodental features and measurements.

\section{MATERIAL AND METHODS}

We examined specimens (see below) housed at the following institutions: American Museum of Natural History (AMNH), New York; Coleção Adriano Lúcio Peracchi (ALP), Instituto de Biologia, Universidade Federal Rural do Rio de Janeiro; Museu Nacional, Universidade Federal do Rio de Janeiro (MN); and Museu de Zoologia da Universidade de São Paulo (MZUSP). Specimens from the type series of $X$. vieirai are de-

2014 Sociedade Brasileira de Zoologia | www.sbzoologia.org.br | www.scielo.br/zool All content of the journal, except where identified, is licensed under a Creative Commons attribution-type BY-NC. 
posited in the latter institution, but the paratype MZUSP 14804 was not available for analysis. Measurements are provided only from adult individuals presenting both phalangeal epiphyses and basisphenoid region completely ossified. Data on hair length and pelage coloration of fluid-preserved specimens were recorded by briefly drying out the body. Hair and ear length were taken with a metallic ruler and all linear measurements were taken with a digital caliper. Condylobasal length was measured from the anteriormost point of the premaxillae (excluding the incisors) to the posteriormost point on the occipital condyles. For other measurements, we followed NogueIra et al. (2012).

Specimens examined. Lionycteris spurrelli Thomas, 1913 (6): Brazil, Minas Gerais (MZUSP 28952-28957); Lonchophylla bokermanni (2): Brasil, Minas Gerais, Diamantina (MN 79996, 79997); Lonchophylla peracchii (Dias, Esbérard \& Moratelli, 2013) (5): Brazil, Rio de Janeiro, Jardim Botânico do Rio de Janeiro (ALP 7418, 7740, 7954, 8013) and Parque Estadual da Pedra Branca (ALP 5820); Lonchophylla mordax Thomas, 1903 (4): Brazil, Minas Gerais, Jaíba (ALP 6840, 6841, 6908, 6909); Lonchophylla thomasi Allen, 1904 (3): Brazil, Acre, Parque Nacional da Serra do Divisor (ALP 7047, 7206, 7247); Platalina genovensium Thomas, 1928 (1): Peru, Arequipa, Carovelli (AMNH 257108); Xeronycteris vieirai (4): Brazil, Minas Gerais, Jaíba (ALP 6824), Bahia, Cocorobó (MZUSP 14170, 14173), and Paraíba, Soledade (MZUSP 29777; holotype).

\section{TAXONOMY}

\section{Xeronycteris vieirai Gregorin \& Ditchfield, 2005}

Xeronycteris vieirai Gregorin \& Ditchfield, 2005:405; type locality "Fazenda Espírito Santo, Município de Soledade, state of Paraíba, Brazil $\left(07^{\circ} 05 \mathrm{~S}, 36^{\circ} 21 \mathrm{~W}\right) . "$

Lonchophylla bokermanni: Griffiths \& Gardner 2008:248, line 36; not Lonchophylla bokermanni Sazima, Vizotto \& Taddei, 1978.

Emended diagnosis. A medium-sized Lonchophyllinae (mean forearm $37 \mathrm{~mm}$ ) with tricolored dorsal fur (cream-white in a basal narrow stripe, pale brown in the middle, and darker brown distally); naked forearm; base of spear of noseleaf, at internarinal region, inserted behind upper limit of horseshoe; lower border of horseshoe entirely fused to face, with no free edge associated with upper lip; lower lip with pair of simple (not scalloped) dermal pads strait along its extension; chin with relatively slight cleft present in midline; foot longer than calcar; thumb relatively short; rostrum slightly longer than braincase and conspicuously tapered anteriorly; zygomatic arch incomplete and reduced to thin projection that follows labial outline of the upper toothrow; medial palate deeply concave and bearing pits lingually adjacent to each molar and, occasionally, also to premolars, allowing insertion of main cusps at lingual side in lower dentition; posterior border of medial palate well-developed; posterior palate concave at midline, and with a broadly U-shaped posterior margin reaching posterior border of optic foramen; glenoid fossae poorly developed; basioccipital pits markedly concave and separated by a thin but high septum; ridge at anterior symphysis of mandible welldeveloped; upper premolars (P3 and P4) lacking cingulum; parastyle anteriorly very extended in M1 and M2; upper molar series extremely reduced, with oclusal plane progressively more lingually oriented from M1 to M3, and mesostyle, metastyle, preprotocrest, postprotocrest, and ectoflexus all missing or greatly reduced, resulting in the virtual absence of a trigon basin; lower dentition reduced with narrowness of premolars, and loss of hypoflexid, metacristid, entocristid, and entoconid.

Redescription. The description of the external morphology (based on the new specimen and the type series): body size medium for the subfamily (mean forearm length from four females $37.15 \mathrm{~mm}$; lonchophyllines ranging from 31-50 mm; Koopman 1994, Woodman \& Timm 2006, Dávalos \& Corthals 2008); muzzle greatly elongated with lower jaw longer than the upper; noseleaf spear prominent (ALP 6824: $4.5 \mathrm{~mm}$ in width and 6.17 $\mathrm{mm}$ in height) and with central rib absent or slightly developed; base of noseleaf spear, at internarinal region, inserted behind upper limit of horseshoe; lower border of horseshoe entirely fused to face, with no free edge associated with upper lip; two distinct dermal pads present just posterior to noseleaf, one on each side of snout; five vibrissae present on each of these pads, two closer to mid-dorsal part of snout, two on middle of pad, and one at base, just posterior to lateral part of horseshoe; genal vibrissae (ventral and/or posterior to the eye) absent; three vibrissae present in interramal region (between the rami of the lower jaws); lower lip with pair of simple dermal pads, not scalloped at edges and almost as strait in middle as in lateral portions; lower lip dermal pads partially fused to each other at midline of chin; relatively slight cleft present in midline of chin posterior to lower lip dermal pads; ears relatively large, rounded at inner margin and tips, and concave at outer margin; tragus about one third of ear length, spatula-shaped, noticeably ticker close to inner margin and without ornamentation, and outer margin marked by lateral, folded back expansion at basal one-third of length of tragus; plagiopatagium inserts distally at ankle; uropatagium relatively long, but shorter in midline producing an arched outline in distal border (between calcars) when tibias arranged in parallel and membrane gently stretched; tail relatively short with tip (ca. $1 \mathrm{~mm}$ ) protruding from dorsal surface of uropatagium; foot longer than calcar; thumb relatively short and densely furred at base; body pelage extending until proximal two-thirds of arm length (forearm is naked) and until base of thighs; ventral surface with uniformly pale brown hairs, frosted at tips, and measuring approximately $5 \mathrm{~mm}$ in length; region above shoulders and at both sides of neck covered by hairs, hairs approximately $7 \mathrm{~mm}$ in length and bicolored (creamwhite at two-thirds basal and toffee brown at tips); dorsal hairs variable in size (from $5 \mathrm{~mm}$ in upper back, at level of plagiopatagium insertion, to approximately $7 \mathrm{~mm}$ at lateral lower 
back); dorsal hairs slightly tricolored (cream-white in a basal narrow stripe, pale brown in middle, and darker brown distally), with external layer frosted at tips. Ears, noseleaf and uropatagium drab in most specimens, but darker in holotype (MZUSP 29777); wing membrane dark brown in all specimens. Craniodental features. The ALP 6824 departs from all specimens in the type series of $X$. vieirai (dental formula I2/2, C1/1, P2/3, M3/3 x $2=34$ ) by presenting one additional upper premolar on each side of the arcade (total of 36 teeth; Fig. 1). This extra upper premolar (assumed to be that after the canine) is smaller in antero-posterior length than the two regular premolars (P3 and P4), but similar to these teeth in presenting small anterior and posterior accessory cusps. In specimens from the type series, P3 is separated from canine by a larger diastema than that between P3 and P4. In ALP 6824, however, these diastemata are similarly reduced (Fig. 1), which might be a consequence of the presence of the extra tooth. Aside from these differences, craniodental characters in ALP 6824 are generally in agreement with those in the type specimens of $X$. vieirai. The following characters were not included in the original description of this taxon, but are shared by all $X$. vieirai we were able to examine: zygomatic arch incomplete and reduced to thin anterior projection that follows labial outline of upper toothrow (broken in most specimens but present on left side of holotype and in ALP 6824); glenoid fossae poorly developed; basioccipital pits markedly concave and separated by thin but high septum; ridge at mandibular symphysis prominent in most specimens (reduced in MZUSP 14170), projected beyond level of lower incisors, and conferring an arched anteriormost profile to ramus in lateral view (Fig. 1); coronoid process broken in most specimens, including holotype, but based on ALP 6824 can be characterized as relatively low; angular process prominent forming posteriormost point of the mandible. As reported in the original description, the medial palate of $X$. vieirai is strongly arched and bearing pits lingually adjacent to each molar. Our analysis, however, showed that these pits can also occur adjacent to premolars. The MZUSP 14170 present pits adjacent to P2 and P3, but only in one side of the arcades.

Comparisons of individual measurements. The specimen of X. vieirai from Jaíba (ALP 6824) is an adult female preserved in alcohol; the skull has been removed and cleaned. The measurements are, in general, very close to those reported here for the two adult females in the type series of $X$. vieirai (Table I). Upper and lower toothrows, however, are slightly larger in ALP 6824. When compared to specimens in the type series of $L$. bokermanni, $X$. vieirai can be promptly differentiated by its shorter forearm, narrower braincase, and longer mandible (Table I).

Remarks. While analyzing the specimens from the type series of X. vieirai we noticed that the holotype (MZUSP 29777), previously reported as a male (see "Type series" section, page 405 , and table 2 , page 409 , both in the original manuscript), is in fact an adult female. In the original tag, where this speci-
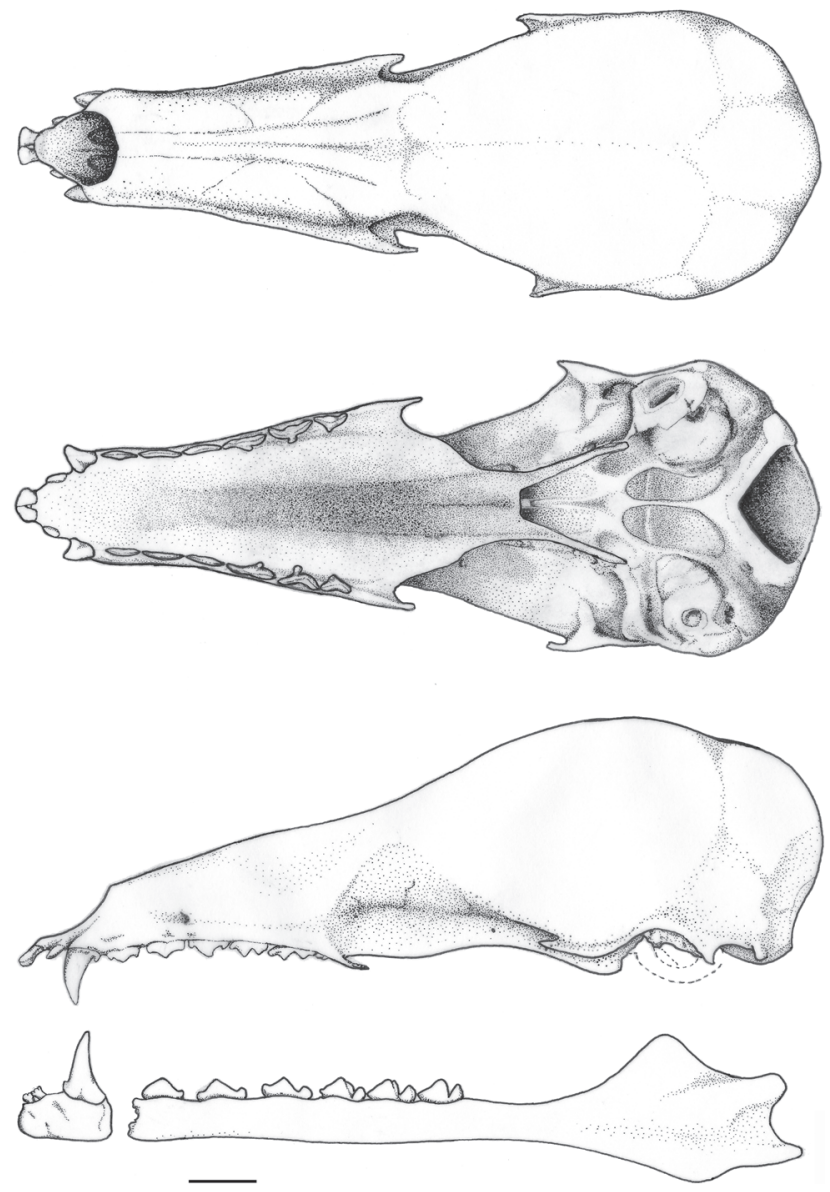

Figure 1. Skull and mandible of Xeronycteris vieirai (ALP 6824) from the region of Jaíba, Minas Gerais, Southeastern Brazil. Scale bar: 2 mm.

men is assigned under the collection number 186020, it is also erroneously reported as a male. The only male available from the type series is, therefore, MZUSP 14173, which is a subadult.

\section{DISCUSSION}

The maximum number of teeth recorded to date for a phyllostomid bat is 34 (Koopman 1994). Therefore, the specimen from Jaíba departs from all described dental formulae in the family. Here we recognize the condition seen in this bat as a congenital dental abnormality. We based our assessment on a morphological analysis showing congruence in diagnostic characters, and on the historical records of dental abnormalities in nectar-feeding bats (Phillips 1971, Lanza et al. 2008). PHillips (1971) assessed the prevalence of supernumerary teeth among glossophagines and lonchophyllines, and found extra first upper premolars in specimens of Glossophaga soricina (Pallas, 1766) and Leptonycteris sanborni Hoffmeister, 1957, but 
Table I. External and cranial measurements (in $\mathrm{mm}$ ) of females of Xeronycteris vieirai from southeastern (ALP 6824) and northeastern Brazil (MZUSP 29777, holotype; MZUSP 14170, paratype), and females of Lonchophylla bokermanni from the type locality in southeastern Brazil (data from SAZIMA et al. 1978).

\begin{tabular}{|c|c|c|c|c|}
\hline \multirow{2}{*}{ Variables } & \multicolumn{3}{|c|}{ X. vieirai } & \multirow{2}{*}{ L. bokermanni } \\
\hline & ALP 6824 & MZUSP 29777 & MZUSP 14170 & \\
\hline Tail length & 6.60 & $8.00^{*}$ & - & - \\
\hline Hindfoot length & 10.84 & $13.00^{*}$ & - & - \\
\hline Calcar length & 4.26 & 4.99 & 5.15 & - \\
\hline Ear length & 12.64 & $10.00^{*}$ & - & - \\
\hline Forearm length & 37.12 & 35.75 & 38.10 & $40.30(40.00-41.30)$ \\
\hline Tibia length & 14.80 & - & - & - \\
\hline Thumb length & 8.22 & 7.82 & 8.71 & - \\
\hline $3^{\text {rd }}$ metacarpal length & 40.14 & - & - & - \\
\hline $1^{\text {st }}$ phalangeal length & 12.89 & - & - & - \\
\hline $2^{\text {nd }}$ phalangeal length & 20.42 & - & - & - \\
\hline $4^{\text {th }}$ metacarpal length & 37.27 & - & - & - \\
\hline $1^{\text {st }}$ phalangeal length & 9.83 & - & - & - \\
\hline $2^{\text {nd }}$ phalangeal length & 12.12 & - & - & - \\
\hline $5^{\text {th }}$ metacarpal length & 34.21 & - & - & - \\
\hline $1^{\text {st }}$ phalangeal length & 9.27 & - & - & - \\
\hline $2^{\text {nd }}$ phalangeal length & 10.50 & - & - & - \\
\hline Greatest length of the skull & 26.07 & 24.98 & 26.25 & $25.67(25.40-26.30)$ \\
\hline Condylobasal length & 24.44 & 23.80 & 24.70 & $24.39(24.00-25.00)$ \\
\hline Condylocanine length & 23.16 & 22.42 & 23.37 & $22.93(22.70-23.50)$ \\
\hline Maxillary toothrow length & 8.59 & 8.10 & 8.16 & $8.19(7.80-8.60)$ \\
\hline Mandibular toothrow length & 9.16 & 8.62 & 8.63 & $8.63(8.20-8.90)$ \\
\hline Mandibular length & 19.30 & - & - & $17.56(17.40-18.00)$ \\
\hline Mastoid breadth & 9.45 & 9.17 & 9.37 & $9.51(9.40-9.60)$ \\
\hline Braincase breadth & 8.66 & 8.61 & 8.62 & $9.43(9.30-9.70)$ \\
\hline Postorbital constriction & 4.69 & 4.73 & 5.00 & $4.93(4.80-5.00)$ \\
\hline Breadth across molars & 5.48 & 5.57 & 5.58 & $5.43(5.20-5.70)$ \\
\hline Breadth across canines & 3.50 & 3.56 & 3.48 & $3.87(3.70-4.00)$ \\
\hline
\end{tabular}

${ }^{*}$ Measurements from original tag.

not in Anoura geoffroyi Gray, 1838. The first two species are similar to $X$. vieirai in presenting two upper premolars as their normal condition, while A. geoffroyi usually presents three upper premolars. We follow PHILLIPs (1971) in recognizing the extra premolars of ALP 6824 as resulting from a genetically determined double initiation in the process of formation of the first upper normal premolars (P3). Such origin is indicated by the presence of two roots in the extra premolars, and by a similarity in size and shape between these teeth and the normal first premolar (PHILLIPs 1971). A recent survey revealed that polyodontia (presence of extra teeth) is rare among bats, occurring in only $8 \%$ of the more than 160 described phyllostomid species (LANZA et al. 2008).

Among the several new characters described here for $X$. vieirai, some are of particular interest, due to their diagnostic value. The tricolored banding pattern in the upper back fur of $X$. vieirai seems to be unique among lonchophyllines (WETTERER et al. 2000), and the general brown body pelage is similar to that seen in $L$. peracchii, but clearly distinct from the paler, ventrally beige $L$. mordax, and the grayish $L$. bokermanni. The entirely naked forearm of Xeronycteris is similar to that of $L$. mordax and Platalina, but it can be used to differentiate this bat from L. bokermanni and L. peracchii, in which the forearm is hairy on the proximal half. Additional external features that may help to discriminate Xeronycteris from L. bokermanni include: the connection of the base of the spear of the noseleaf with the upper limit of the horseshoe, which is smooth in the latter species (and in L. mordax), while it is marked by a ridge in $X$. vieirai; the shape of dermal chin pads, which are simple in X. vieirai vs. scalloped in L. bokermanni (apparently extensive to whole genus - WetTERER et al. 2000); the presence of a relatively slight cleft on the chin (just after the dermal pads), which is absent in L. bokermanni (again this latter condition seems to be extensive to whole genus - WetTerer et al. 2000); and the relative length of the thumb (shorter in $X$. vieirai ) and noseleaf spear (shorter in L. bokermanni). 
When cleaned skulls and mandibles are available, the following additional characters are noteworthy: anterior zygomatic arches reduced and not extending laterally and upward with respect to upper toothrow, as in other lonchophyllines; basioccipital pits deeper and separated by higher and thinner bone septum than in L. bokermanni, L. mordax, and L. peracchii; and ridge at anterior symphysis more pronounced than in other lonchophyllines, extending well beyond the lower incisors.

We have emphasized here comparisons with L. bokerman$n i$ because in eastern Brazil this species is the most likely to be confused with $X$. vieirai. As revealed by original notations in specimens tags, the paratypes of $X$. vieirai MZUSP 14170 and 14173 were first referred to as L. bokermanni, which might explain the erroneous record of this latter species from Cocorobó, Bahia - Griffiths \& GARDNER (2008) based this record on the MZUSP 14170 -. As currently accepted, L. bokermanni is restricted to the state of Minas Gerais, southeastern Brazil (DiAs et al. 2013), and its type series came from an area of Cerrado less than $500 \mathrm{~km}$ from the meridional limit in the distribution of X. vieirai (NogueIra et al. 2007). These two endemic species are listed as threatened in regional lists (e.g., Paglia et al. 2009), but according to the last IUCN assessment they are still datadeficient, requiring more information for a reliable determination of their conservation status (SAMPAIO et al. 2008, DitchFieLd \& GREGORIN 2008). In either case, these species should be focus of ecological and natural history investigations, ideally funded on a clear recognition of their taxonomic identity, particularly under field conditions, as supported by data presented here.

\section{ACKNOWLEDGMENTS}

We are thankful to Mário de Vivo (Museu de Zoologia, Universidade de São Paulo, Brazil), Nancy B. Simmons (American Museum of Natural History, EUA), and João Alves de Oliveira (Museu Nacional, UFRJ) for allowing access to specimens under their care; to Juliana Barros (Museu de Zoologia, Universidade de São Paulo), Eileen Westwig (American Museum of Natural History), and Marcione Brito de Oliveira for assistance in finding specimens in their respective institutions; to Jair Silva for the careful preparation of the skull and mandible illustrations of $X$. vieirai; to $\mathrm{CNPq}$ for financial support to Marcelo R. Nogueira (Programa Nacional de Pós-doutorado CNPq/Capes/Finep, process 151559/2008-2), Renato Gregorin (process 310490/2009-0), and Adriano L. Peracchi (process 303622/2009-1); and to FAPEMIG for financial support to Renato Gregorin (processes APQ 03504-09 and PPM-00173-13).

\section{LITERATURE CITED}

Astúa, D. \& D.Q. Guerra. 2008. Caatinga bats from Mammal Collection of the Universidade Federal de Pernambuco. Chiroptera Neotropical 14: 326-338.
Dias, D.; C.E.L. Esbérard \& R. Moratelli. 2013. A new species of Lonchophylla (Chiroptera, Phyllostomidae) from the Atlantic Forest of southeastern Brazil, with comments on L. bokermanni. Zootaxa 3722 (3): 347-360.

DÁvalos, L.M. \& A. Corthals. 2008. A new species of Lonchophylla (Chiroptera: Phyllostomidae) from the eastern Andes of northwestern South America. American Museum Novitates 3635: 1-16.

Ditchileld, R. \& A.D. Gregorin. 2008. Xeronycteris vieirai. In: IUCN (Ed.). IUCN Red List of Threatened Species. Version 2012.2. Available online at: http://www.iucnredlist.org [Accessed: 10/III/2013].

Gregorin, R. \& A.D. Ditchfield. 2005. New genus and species of nectar-feeding bat in the tribe Lonchophyllini (Phyllostomidae: Glossophaginae) from northeastern Brazil. Journal of Mammalogy 86 (2): 403-414. doi: http://dx.doi.org/ 10.1644/BRB-229.1.

Griffiths, T.A. \& A.L. Gardner. 2008. Subfamily Glossophaginae Bonaparte, 1845, p. 224-244. In: A.L. GARDNER (Ed.). Mammals of South America, Volume I. Marsupials, Xenarthrans, Shrews, and Bats. Chicago, University of Chicago Press.

Koopman, K.F. 1994. Chiroptera: Systematics. New York, Walter de Gruyter, Handbook of Zoology, vol. 8, part 60, 217p.

LANZA, B.; M. Riccucci \& U. FunAIOLI. 2008. An interesting case of polyodontia in Epomophorus wahlbergi, with a review of this dental anomaly in bats (Chiroptera). Lynx 39 (1): 109-127.

Nogueira, M.R.; A.L. Peracchi \& R. Moratelli. 2007. Subfamília Phyllostominae, p. 61-97. In: N.R. Reis; A.L. Peracchi; W.A. Pedro \& I.P. Lima (Eds). Morcegos do Brasil. Londrina, Nélio R. dos Reis, 253p.

Nogueira, M.R.; I.P. Lima; A.L. Peracchi \& N.B. Simmons. 2012. New genus and species of nectar-feeding bat from the Atlantic forest of southeastern Brazil (Chiroptera: Phyllostomidae: Glossophaginae). American Museum Novitates 3747: 1-30.

Novaes, R.L.M.; F.A.P. Mello; S. Felix; R. Silvares; C. Sant'Anna; A.C.S. FaÇanha; T.S. Cardoso; M.A.S. Louro; R.F. Souza; M.V.P. Aguiar; A.C. Siqueira \& C.E.L. Esbérard. 2010. Lonchophylla bokermanni na Floresta Atlântica: distribuição, conservação e nova localidade de ocorrência para uma espécie ameaçada de extinção. Chiroptera Neotropical 16 (2): 710-714.

Paglia, A.; A.G. Chiarello; F.R. Melo; V.C. Tavares \& F.H. Rodrigues. 2009. Mamíferos, p. 297-314. In: G.M. Drummond; C.S. Martins; M.K.B. Greco \& F. Vieira (Eds). Biota Minas: diagnóstico do conhecimento sobre a biodiversidade no Estado de Minas Gerais - subsídio ao Programa Biota Minas. Belo Horizonte, Fundação Biodiversitas.

Phillips, C.J. 1971. The dentition of Glossophaginae bats: development, morphological characteristics, variation, pathology, and evolution. Miscellaneous Publications of the Museum of Natural History, University of Kansas 54: 1-138.

Pimenta, V.T.; C.T. Machel; B.S. Fonseca \& A.D. Ditchfield. 2010. First occurrence of Lonchophylla bokermanni Sazima, Vizotto 
and Taddei, 1978 (Phyllostomidae) in Espírito Santo State, Southeastern Brazil. Chiroptera Neotropical 16 (2): 740-742.

Sampaio, E.; B. Lim \& S. Peters. 2008. Lonchophylla bokermanni. In: IUCN (Ed.). IUCN Red List of Threatened Species. Version 2012.2. Available online at: www.iucnredlist.org [Accessed: 10/III/2013].

Sazima, I.; L.D. Vizotto \& V.A. Taddei. 1978. Uma nova espécie de Lonchophylla da Serra do Cipó, Minas Gerais, Brasil (Mammalia, Chiroptera, Phyllostomidae). Revista Brasileira de Biologia 38: 81-89.

Wetterer, A.L.; M.V. Rockman \& N.B. Simmons. 2000. Phylogeny of phyllostomid bats (Mammalia, Chiroptera): data from diverse morphological systems, sex chromosomes, and restriction sites. Bulletin of the American Museum of
Natural History 248: 1-200.

WoOdman, N. 2007. A new species of nectar-feeding bat, genus Lonchophylla, from western Colombia and western Ecuador (Mammalia: Chiroptera: Phyllostomidae). Proceedings of the Biological Society of Washington 120 (3): 340-358. doi: http://dx.doi.org/10.2988/0006-324X(2007)120[340: ANSONB]2.0.CO;2

Woodman, N. \& R.M. Timm. 2006. Characters and phylogenetic relationships of nectar-feeding bats, with descriptions of new Lonchophylla from western South America (Mammalia: Chiroptera: Phyllostomidae: Lonchophyllini). Proceedings of the Biological Society of Washington 119 (4): 437-476. doi: http://dx.doi.org/10.2988/0006-324X(2006)119[437: CAPRON]2.0.CO;2

Submitted: 13.VI.2013; Accepted: 08.IX.2013.

Editorial responsability: Fernando de C. Passos 